\title{
ANXIETY, SELF-ESTEEM AND COPING WITH STRESS IN SECONDARY SCHOOL STUDENTS IN RELATION TO INVOLVEMENT IN ORGANIZED SPORTS ANKSIOZNOST, SAMOSPOŠTOVANJE IN SPOPRIJEMANJE S STRESOM PRI SREDNJEŠOLCIH V POVEZAVI Z VKLJUČENOSTJO V ORGANIZIRANO ŠPORTNO AKTIVNOST
}

\author{
Petra DOLENC ${ }^{1 *}$
}

\author{
${ }^{1}$ University of Primorska, Faculty of Education, Cankarjeva 5, 6000 Koper, Slovenia
}

\section{ABSTRACT}

Keywords:

mental health, coping with stress, adolescents, sports

\section{IZVLEČEK}

Ključne besede: psihično zdravje, spoprijemanje s stresom, mladostniki, šport
Aim. The objective of the study was to examine self-esteem, anxiety level and coping strategies among secondary school students in relation to their involvement in organized sports.

Methods. The sample included 280 Slovenian male and female secondary school students aged between 15 and 19 years. The participants completed The Adolescent Coping Scale, the Spielberger State-Trait Anxiety Inventory, and the PSDQ Selfesteem Scale.

Results. Participants engaged in organized sports exhibited higher self-esteem scores and lower anxiety scores in comparison to non-sport participants. Differences between the two groups have also been identified with respect to the use of certain coping strategies. Sport participants reported more productive coping than non-sport participants, which represents an active and problem-focused approach to dealing with everyday problems. Gender differences in the referred variables have also been studied, with female athletes exhibiting higher levels of anxiety than male athletes. Female participants were also found to use more non-productive coping than males, focused mainly on reducing emotional effects of stress.

Conclusions. Organized youth sports have an important role in improving and maintaining a favorable sense of self-worth, reducing anxiety, and promoting productive coping strategies in adolescents when dealing with everyday problems.

Cilj. Namen raziskave je bil preučiti raven samospoštovanja in anksioznosti ter uporabo različnih strategij spoprijemanja s stresom pri srednješolskih mladostnikih $v$ povezavi $z$ vključenostjo $v$ redno in organizirano športno vadbo.

Metode. Vzorec je obsegal 280 slovenskih srednješolcev in srednješolk od 15. do 19. leta. Udeleženci so izpolnili vprašalnik spoprijemanja s težavami za mladostnike, lestvico anksioznosti in lestvico samospoštovanja.

Rezultati. Pri mladostnikih, ki se organizirano ukvarjajo s športom, smo ugotovili višje vrednosti na lestvici samospoštovanja in nižjo stopnjo anksioznosti $v$ primerjavi z njihovimi športno neaktivnimi vrstniki. Razlike med skupinama so se pokazale tudi v uporabi nekaterih spoprijemalnih strategij: športno aktivni mladostniki so se $v$ splošnem posluževali več na problem usmerjenih strategij spoprijemanja $v$ primerjavi z nešportniki, kar kaže na bolj aktiven in konstruktiven pristop $k$ reševanju vsakodnevnih težav. Razlike po spolu so pokazale, da športnice izražajo več anksioznega doživljanja kot športniki. Na področju soočanja s stresom smo ugotovili razlike $v$ nekaterih spoprijemalnih strategijah tako $v$ skupini športnikov kot $v$ skupini nešportnikov: dekleta so $v$ primerjavi s fanti izražala več nekonstruktivnega spoprijemanja, usmerjenega predvsem $v$ blaženje učinkov čustvene napetosti $v$ stresnih situacijah.

Zaključek. Predpostavimo lahko, da ima organizirana športna aktivnost pomembno vlogo pri razvijanju in ohranjanju ugodnega občutka lastne vrednosti, zmanjševanju negativnih učinkov stresa ter spodbujanju uporabe aktivnih in konstruktivnih strategij spoprijemanja s težavami v mladostništvu. 


\section{INTRODUCTION}

Numerous studies have confirmed that daily physical activity (PA) is important to improve health and protect against a variety of physical and psychological conditions in young people (1). Regular PA has numerous short- and long-term benefits, which are reflected in improved physical fitness, reduced risk of overweight and obesity, enhanced bone health, and decreased health risk factors for cardiovascular disease and metabolic syndrome (2). Appropriate amount of PA is not only imperative for good physical health, but it has a significant influence on adolescent's psychological well-being (3).

In the last fifteen years, many sudies have focused on the psychological and social health benefits of sport participation in children and adolescents (4). Sport is viewed as one of the most popular leisure-time activities, and it is often organized in the form of sports clubs or extracurricular PA in schools (5). Some longitudinal studies have shown that participation in youth sport, and persitent participation, in particular, significantly predict adult PA (6).

Several studies have found that participation in PA and sports is associated with increased sense of self-worth (7), better physical self-concept and overall self-esteem of adolescents $(8,9)$. Donaldson and Ronan examined the relationship between participation in organized sport practice and emotional and social adjustment in early adolescence. They found that adolescents participating in more formal sports exhibited less emotional and behavioral problems compared to those participating in fewer formal sports (10). Similarly, a study conducted on a sample of 16-20-year-old adolescents showed that individuals with greater frequency of sports participation (at least twice a week) reported better feelings of wellbeing compared to those who participated less than once a week (11). In a three-year longitudinal study of club sport participation during adolescence, Brettschneider concluded that adolescents in sports clubs had a more positive self-concept when compared to their non-member peers (12). Snyder and collegues examined health-related quality of life measures of students in relation to club sports participation: athletes reported higher scores on physical functioning, general health, social functioning and mental health scales than non-athletes (13). Hansen, Larson and Dworkin emphasizedthe importance of structured sports activity in the acquisition of some relevant skills and experiences for adolescents: setting achievable, realistic goals, improving time management skills, which are associated with planning their own activities, regulation and control of PA, learning about their own resources and limitation, improving problemsolving and decision-making skills (14). Research also suggested that organized youth sports can be an arena for social skills development, such as cooperation, empathy and self-control, positive peer relation, responsibility and leadership skills (15). In the study conducted by Mahoney and Stattin, organized youth sports were linked to lower levels of antisocial behavior (16).

Besides all the the positive benefits of sports, there are also some negative outcomes, expecially in highly competitive sports. Excessive physical activity can lead to many sportrelated injuries and health problems among athletes (17). Fraser-Thomas and Côte indicate an important link between elite youth sport, eating disorders and pressure to win (18). These authors also point to the fact that youth sports today are more than ever characterized by early specialization, focusing on competition at earlier ages and earlier selection (19).

Adolescence represents an important developmental transition from childhood to adulthood that involves numerous physiological, psychological and social changes (20). This period brings a variety of potential stressors, such as changes in responsibilities, higher academic requirements, different interpersonal relationships, including peers and friends, parents and romantic relations, and also concerns about one's future (21). At the same time, adolescence is crucial in developing a repertoire of effective coping strategies. Coping is defined as 'the cognitive, behavioral efforts to manage particular external and/or internal demands that are appraised as taxing or exceeding resources of a person (22). It is a complex and multidimensional process that is sensitive to both the environment and personality of an individual (23). Characteristics of coping behavior in adolescents are reflected in their ways of dealing with stress in later life. Numerous studies have emphasized that knowledge and use of constructive coping have a significant influence on various dimensions of psychological adaptation and wellbeing in adolescents (24). Some research findings have indicated that PA and physical fitness are viable means of reducing stress among secondary school students (25). In a cross-sectional study of Greek late adolescents, positive correlations were found between proactive coping strategies, moderate PA and self-efficacy (26).

However, less research has been done on psychological and social benefits of regular sport involvement among Slovenian adolescents, particuarly in terms of sports club participation. Furthermore, there is a lack of research focusing on coping with stress in relation to sport practice in adolescents. Thus, the study aimed to examine anxiety, self-esteem and coping strategies among secondary school students in relation to their involvement in organized sports activities. Also gender differences in the psychological variables were tested, specifically in sport and non-sport participants. Moreover, the relationship between coping, anxiety and self-esteem was determined. 


\section{METHODS}

\subsection{Participants}

Participants in this study were 280 secondary school students aged 15-19 years (140 males, 140 females) from Slovenian urban areas. The inclusion criteria were the absence of serious health problems and chronic diseases, as well as of physical disabilities and the problems related to them. Two groups were created: athletes $(n=140$; age $M=16.6, S D=1.1)$ and non-athletes $(n=140$; age $M=16.7, S D=1.2$ ). The group of athletes ( 70 males, 70 females) included those adolescents, who were regularly engaged in organized sports in sports clubs over the past twelve months. Among them, there were 76 team-sport athletes (basketball, volleyball, soccer, handball) and 64 individual-sport athletes (athletics, swimming, rowing, gymnastics, sailing, archery, cycling). The frequency of exercise trainig among athletes ranged from two times per week to six times per week. The group of non-athletes consisted of adolescents that did not actively participate in sports and were not members of a sports club. In order to equalize the groups according to relevant characteristics (age, gender, school education (evel), the non-athletes group was selected on the basis of the characteristics of each member of the athlete group using the equivalent-groups method (27). All participants attended the gymnasium and had the same number of physical education classes. There was no age difference $(\mathrm{t}=-1.02 ; \mathrm{p}=.31)$ between athletes and non-athletes.

\subsection{Instruments}

The Slovenian version of the Adolescent Coping Scale (ACS) was used to determine coping behavior among adolescents (28). The ACS scale, developed originally by Frydenberg and Lewis, is a self-report instrument that includes 79 items (29). Adolescents were asked to report how frequently they used any of the 18 coping strategies on a 5-point scale (from 1 - doesn't apply or don't do it, to 5 - used a great deal). According to the Slovenian adaptation of the ACS coping, strategies are classified in two main coping styles. The first one is productive coping, which represents functional strategies, such as direct attempts to confront the problem with or without reference to others. The second style can be seen as non-productive coping, as it includes mostly dysfunctional strategies that relate primarily to relieving negative feelings when faced with a stressful situation (e.g. avoidance, self-blame, ignoring, wishful thinking). In this study, a general form of the instrument was used; participants were asked to respond based on their coping with everyday difficulties and problems (e.g. with family, school, friends). The evidence of adequate reliability and validity of the ACS has been reported (28).

State Trait Anxiety Inventory (STAI) was used to determine the anxiety level among participants (30). STAl is a well standarized, self-report instrument, designed to measure both state and trait anxiety. For the purpose of the study, only the part of the instrument that relates to trait anxiety (STAI-X2) was assessed. The STAI-X2 includes 20 descriptive statements, on the basis of which participants express the way they feel in general on a 4-point scale (from 1 - never, to 4 - almost all the time). Trait anxiety refers to relatively stable individual differences manifested in the tendency to react to situations perceived as threatening with an increase in state anxiety. Values range from 20 to 80 , with higher score indicating greater anxiety level. The inventory is among the most widely used measures of general anxiety. Content validity of the Slovenian version of the STAI was determined on the basis of strong associations with other anxiety measures $(r=0.80$ between the STAI and the Manifest Anxiety Scale), and the internal consistency was very high, $a=0.88$ (30).

The Self-esteem Scale from the Physical Self-Description Questionnaire (PSDQ) was used to assess overall selfesteem of adolescents (31). Participants were asked to answer to eight items (e.g. 'I have a lot to be proud of.') on 6-point scale ( 1 - false, 2 - mostly false, 3 - more false than true, 4 - more true than false, 5 - mostly true, 6 - true). The scores are computed by averaging the responses to all the scale items, where higher values indicate a higher self-esteem. In evaluating the psychometric properties of the original instrument, good validity and reliability were demonstrated (31).

\subsection{Procedure}

Prior to data collection, the permission to conduct the study was obtained from school heads. The purpose of the study and the procedures were explained to the participating students and a written informed consent was obtained from their parents. Participants completed the instuments at school, during physical education classes in the presence of the author of this study. All data were kept anonymous to assure confidentiality. The study was aproved by the Ethics Committee for Sport at the Faculty of Sport, University of Ljubljana.

\subsection{Statistical Analysis}

In addition to descriptive statistics, Cronbach's alpha was calculated to assess internal consistency of the instruments. Mann-Whitney test was used to determine differences between the groups (athletes vs. non-athletes, males vs. females). The Spearman coefficient was used to calculate correlations between coping, anxiety, and selfesteem. Multiple regression analysis was conducted to assess whether the variables above significantly predicted coping behavior in adolescents. The significance level was set at $\mathrm{p}<.05$. 


\section{RESULTS}

\section{1 Internal Consistency}

Alpha coefficients of the STAI-X2 and the PSDQ Selfesteem Scale were 0.89 and 0.86 , respectively, indicating good internal consistency. Coefficients alpha for 14 of the 18 ACS subscales were considered acceptable; however, because the Tension Reduction, Seek to Belong, Relaxing Diversion and Social Action subscales had poor internal consistency (e.g., $a=0.57$ ), they were excluded from further analysis.

\subsection{Descriptive Statistics}

Participants have above-average score on the PSDQ selfesteem scale and low anxiety score measured by the STAI-X2. According to the ACS, the coping strategies most frequently used were Solving the Problem, Seek Social Support, Work Hard, Invest in Close Friends, Wishful Thinking, and Worry. The least common strategies used by students were Seek Spiritual Support and Seek Professional Help (Table 1).

Table 1. Descriptive statistics (M, SD) of STAI-X2, PSDQ Selfesteem Scale and ACS subscales $(\mathrm{N}=280)$.

\begin{tabular}{lcccc}
\hline & $M$ & SD & Skewness & Kurtoisis \\
\hline STAI-X2 & 39.73 & 8.74 & 0.370 & -0.265 \\
PSDQ Self-esteem Scale & 38.20 & 5.81 & -0.635 & 0.146 \\
ACS subscales & & & & \\
Seek Social Support & 16.13 & 3.07 & -0.280 & -0.015 \\
Solving the Problem & 18.45 & 2.56 & -0.238 & -0.212 \\
Work Hard & 17.93 & 2.55 & -0.120 & 0.954 \\
Worry & 15.12 & 3.51 & 0.002 & -0.311 \\
Invest in Close Friends & 14.94 & 3.23 & -0.049 & -0.213 \\
Wishful Thinking & 15.82 & 3.22 & 0.093 & -0.316 \\
Not Coping & 11.22 & 3.04 & 0.529 & 0.431 \\
Ignore the Problem & 8.63 & 2.38 & 0.098 & -0.369 \\
Self-blame & 11.45 & 2.79 & -0.002 & 0.037 \\
Keep to Yourself & 10.04 & 2.72 & 0.270 & 0.416 \\
Seek Spiritual Support & 6.83 & 3.38 & 1.240 & 0.700 \\
Focus on the Positive & 13.21 & 2.55 & -0.395 & 0.415 \\
Seek Professional Help & 7.01 & 2.88 & 0.951 & 0.242 \\
Physical Recreation & 11.9 & 3.12 & -0.520 & -0.607 \\
\hline & & & & \\
\hline
\end{tabular}

\subsection{Differences in Psychological Measures between Groups}

Since the Kolmogorov-Smirnov test revealed that most of the data did not follow normal distribution, the MannWhitney test was used to determine differences in psychological variables between athlete and non-athlete groups. The results are presented in Table 2 . Athletes scored significantly higher on self-esteem $(p<.001)$ and lower on trait anxiety scale $(p<.01)$ compared to nonathletes. With respect to coping behavior, assessed by the ACS, athletes applied considerably more the strategies Physical Recreation $(p<.001)$, Invest in Close Friends $(p<.01)$, Focus on the Positive $(p<.01)$, Seek Professional Help $(p<.01)$ compared to non-athletes, who reported higher scores on the strategies Not Coping $(p<.05)$ and Worry $(p<.05)$ than athletes.

Table 2. Differences between adolescent athletes and non-athletes in psychological measures.

\begin{tabular}{|c|c|c|c|c|}
\hline & $\begin{array}{l}\text { Athletes } \\
\text { Mean } \\
\text { rank }\end{array}$ & $\begin{array}{c}\text { Non- } \\
\text { athletes } \\
\text { Mean rank }\end{array}$ & $u$ & $p$ \\
\hline STAI-X2 & 126.54 & 154.46 & 7845.5 & .004 \\
\hline PSDQ Self-esteem Scale & 159.75 & 121.25 & 7105.5 & .000 \\
\hline \multicolumn{5}{|l|}{ ACS subscales } \\
\hline Seek Social Support & 143.89 & 137.11 & 9325.0 & .481 \\
\hline Solving the Problem & 139.30 & 141.70 & 9632.5 & .803 \\
\hline Work Hard & 146.79 & 134.21 & 8203.5 & .190 \\
\hline Worry & 129.09 & 151.91 & 8203.0 & .018 \\
\hline Invest in Close Friends & 156.23 & 124.77 & 7597.5 & .001 \\
\hline Wishful Thinking & 138.23 & 142.78 & 9481.5 & .637 \\
\hline Not Coping & 128.10 & 152.90 & 8045.5 & .010 \\
\hline Ignore the Problem & 143.55 & 136.47 & 9236.0 & .460 \\
\hline Self-blame & 139.70 & 141.30 & 9688.5 & .868 \\
\hline Keep to Yourself & 138.54 & 142.46 & 9525.0 & .683 \\
\hline Seek Spiritual Support & 139.09 & 141.91 & 9602.5 & .764 \\
\hline Focus on the Positive & 154.74 & 126.26 & 7806.5 & .003 \\
\hline Seek Professional Help & 154.89 & 126.11 & 7785.0 & .003 \\
\hline Physical Recreation & 197.52 & 83.48 & 1817.0 & .000 \\
\hline
\end{tabular}

Gender differences in the studied psychological variables were also determined. No differences were found in selfesteem, whereas females scored significantly higher on anxiety scale compared to males, but only in the group of athletes $(\mathrm{U}=1806.5, \mathrm{p}=.007)$. According to coping 
strategies in the group of athletes, females showed greater use of Seek Social Support $(U=1473, p=.000)$, Self-blame $(U=1731.5, p=.002)$, Not Coping $(U=1762.5$, $\mathrm{p}=.004)$, and Wishful Thinking $(\mathrm{U}=1852, \mathrm{p}=.012)$ than males, whereas males exhibited greater use of Seek Professional Help $(U=1520.5, p=.000)$ and Ignore the Problem $(U=1922, p=.036)$. In non-athletes, gender differences were very similar to those in athletes. Female non-athletes showed greater use of Seek Social Support $(U=1593, p=.000)$, Not Coping $(U=1785, p=.009)$, and Self-blame $(U=1850, p=.012)$ compared to male non-athletes; the letter showed more frequent use of Seek Professional Help $(U=1632, p=.000)$ and Ignore the Problem $(U=1798, p=.006)$ than female non-athletes.

\subsection{Relationship among Psychological Variables}

In both athlete and non-athlete students, self-esteem score was negatively correlated with trait anxiety and a non-productive coping style, and positively correlated with a productive coping style. Trait anxiety was positively correlated with non-productive coping and negatively correlated with productive coping (Table 3).

Table 3. The correlation between anxiety (STAI-X2), selfesteem (PSDQ) and coping styles (ACS) for athletes (below the diagonal) and for non-athletes (above the diagonal).

\begin{tabular}{lcccc}
\hline & 1 & 2 & 3 & 4 \\
\hline STAI-X2 & & $-.62^{* * *}$ & $-.26^{* *}$ & $.58^{* * *}$ \\
PSDQ Self-esteem Scale & $-.56^{* * *}$ & & $.42^{* * *}$ & $-.39^{* * *}$ \\
ACS - Productive coping & $-.21^{*}$ & $.32^{* * *}$ & & -.03 \\
$\begin{array}{l}\text { ACS - Non-productive } \\
\text { coping }\end{array}$ & $.35^{* * *}$ & $-.20^{*}$ & .05 & \\
\hline
\end{tabular}

In order to establish whether anxiety and self-esteem predicted the coping styles used, two regressions were conducted. The first regression included psychological variables and productive coping. The results indicated that anxiety and self-esteem together accounted for $13 \%$ of variance $(F=10.46, p=.000)$ in athletes and $19 \%$ of variance $(F=16.45, p=.000)$ in non-athletes. Only selfesteem significantly predicted productive coping in both athletes $(B=0.34, p=.000)$ and non-athletes $(B=0.50$, $p=.000)$. The second regression included psychological variables and non-productive coping. Anxiety and selfesteem together accounted for $13 \%$ of variance $(F=10.35$, $p=.000)$ in athletes, and $32 \%$ of variance $(F=31.99$, $\mathrm{p}=.000)$ in non-athletes. Only anxiety significantly predicted non-productive coping in both athletes $(B=0.38, p=.000)$ and non-athletes $(B=0.53, p=.000)$.

\section{DISCUSSION}

In the study, we focused on the examination of coping with stress in secondary school adolescents in relation to involvement in organized sport practice. The study aimed to determine the relationship between self-esteem, anxiety and ways of coping with stress in adolescents. With regards to daily problems as a source of stress, adolescents use different coping strategies, which points to a high degree of flexibility in responding to problems and thus to better adaptation capacities (32). In general, adolescents avail themselves of predominantly positive and constructive ways of coping with problem situations, including social support seeking, which is consistent with the findings of previous studies (33). In spite of some similarities in the use of coping strategies in the group of athletes and non-athletes, there are also some significant differences between them. In comparison with non-athletes, athletes indicated sports activities that support maintainance of physical fitness as a way of coping with stress much more often. In comparison with non-athletes, athletes, expressed more intensive orientation into establishing and maintaining friendship relations and readiness to accept professional help in problem situations. Adolescent athletes are faced with similar everyday stressing situations as other peers and, in addition, also with specific requirements related to sport. Active involvement in sport activity that assumes organized and systematic training and includes various pre-competition and competition situations, can mean more expressed need for connecting and co-operating with coaches, with other professionals in the field of sport as well as with other athletes. Such 'turning to others' certainly has a positive sign as it shows that in 'faced with a problem' situations, an individual is more receptive to information and support from others, mainly from professionally qualified persons. In managing difficulties, athletes demonstrated a more serene and optimistic life orientation than non-athletes. The latter can be related to the findings of a study on secondary school population in which a positive correlation between optimism and engagement in sport was reported (34). On the other hand, adolescents who were not regularly involved in sports activities adopted more emotion-focused coping strategies: they expressed more concern about their present and future, and more insecurity and psychosomatic symptoms in relation to problems they have to cope with, when compared to active sport participants.

The obtained results are consistent with the findings of Kamtios and Filaktakidou who report positive correlations between proactive coping, moderate physical activity, and self-efficiency of adolescents (26). In the study of Smojver-Ažić and colleagues, however, no significant differences were found in problem-focused coping between adolescent athletes and non-athletes (35). It 
can be concluded that regular sports activities play an important role in reducing psychological burden, and contribute to develop more effective skills for coping with problems in adolescents. In our research, we found out that young athletes use more constructive ways of dealing with problems than their peers who are not involved in sports on a regular basis. This may mean that there are also differences in experiencing stress, or differences in the evaluation of stressful situations between the two groups. Based on the results, we see that athletically active adolescents showed higher self-esteem and lower trait-anxiety, which could affect the fact that they experienced more control over stressful situations, or that they experienced those situations as less threatening. In addition, other studies indicated that young athletes had higher scores in self-esteem compared to their peers with dominant leisure-time sedentary behavior (36), and that participation in organized sports was associated with a reduction of anxiety among adolescents (37). A recent research conducted on elementary school children showed that participants involved in sport activities, in out-of school time, reported higher levels of self-perceived sport competence and greater self-esteem compared to students not engaged in sport activities (38).

When compared with female athletes, male athletes showed lower levels of anxiety. Previous research (39) also confirmed significant differences in trait and state anxiety between sportsmen and sportswomen. In a more recent study, which examined the level of anxiety, assessment of stress and coping strategies among young sport participants, girls expressed a higher level of anxiety, perceived more situations as threatening and more often used emotion-focused coping strategies compared with boys (40). Our data are largely consistent with the findings of other studies, linking stronger feelings of tension and worry in girls with their greater susceptibility to a variety of stressful events, compared with boys (41).

The differences between girls and boys were examined in the ways of coping for athletes and non-athletes. Gender differences in both groups showed similar results: girls more likely than boys stated the use of certain strategies related to the mitigation of emotions, such as the inability to deal with a problem, self-blame and withdrawal from problem situations, while boys used more frequently some other strategies, such as ignoring the problem and mental distancing. Furthermore, the girls showed a greater need for support from other people, while, in difficult situations, boys more frequently reached for professional help. The results were also comparable with many previous studies, which reported that, compared with boys, girls have more pronounced emotion-focused coping, and seek more for social support $(42,43)$. From our results it is clear that 'reference to others' is also present in boys, but it appears that, when they search for social support, it has a particularly instrumental function (resulting in a significantly higher expression of the search of technical assistance), while, with girls, social support has a more emotional function (the search for contact with others, expressing feelings, a relief through conversation). The reasons for these gender differences in coping behavior are many and varied. One possible explanation is certainly the emergence of differences in the socialization process, as a result of gender role stereotypes and expectations that are conveyed through social environment. Some authors point out that the differences in coping behavior reflect differences in the assessment of stress among male and female adolescents. The results of various studies show quite unanimously that female adolescents assess stressful situations as more negative (24) and, compared with males, report experiencing higher numbers of different stressful events (44).

Based on determining the relationship between selfesteem, anxiety and coping, we found that the adolescents who showed more anxiety and tension, expressed an increased use of strategies aimed at mitigating emotions when faced with a stressful situation, and less use of problem-focused strategies (e.g., planning, taking action, seeking assistance). Furthermore, a number of other studies on coping in adolescents report that problem-focused coping is associated with lower levels of anxiety and, conversely, that emotion-focused coping (e.g., wishful thinking, self-blame) is associated with higher levels of neuroticism (42). As expected, there is a strong negative correlation between anxiety and selfesteem: the adolescents who highly appreciate and accept themselves as they are usually show a lower level of anxiety. Many previous studies have also shown a significant negative correlation between general selfesteem and the level of anxiety in adolescents (45). Furthermore, the regression analysis showed that anxiety is more important in predicting emotion-focused coping, while self-esteem significantly predicts problem-focused coping among adolescents. In the models of stress, trait anxiety represents a significant predictor variable, so it can be assumed that a higher level of anxiety affects the perception of stress as more threatening, which will result in a more defensive response, primarily focused on the reduction of emotional tension due to the stressful situation (46). Self-esteem has a greater role in assessing control of a situation. Stable personal characteristics, such as optimism, personal mastery and high self-esteem, promote effective coping with stress and have direct effects on mental and physical health (47).

\section{CONCLUSION}

Based on the results of the study, it can be reasonably 
assumed that regular and organized sports activity is an important factor that contributes to reducing the negative effects of stress, as reflected in a lower anxiety level, and that it promotes the use of active and constructive strategies of coping with stress in adolescents.

The present study has important implications for adolescent health promotion. Research findings can encourage critical reflection on, and concrete action towards creating appropriate and accessible sport progammes, which would allow the development and maintainance of favorable self-esteem and effective coping strategies among adolescents. The results should serve all who, working with young people, are responsible for the promotion of healthy lifestyles and advocate increased leisure time physical activity for children and adolescents.

It should be noted, though, that the findings cannot be generalized to the entire Slovenian secondary school population, because the sample was restriced to adolescents attending gymnasiums in three major Slovenian cities. Thus, future research should include also adolescents from rural areas in order to achieve a greater generalizability of the results.

The relationship between psychological well-being and sports activity certainly deserves further in-depth research. Longitudinal and intervention studies are also needed to determine the causal direction of the associations between sport involvement and the examined psychological variables. Namely, it would be necessary to investigate whether the significant differences between the studied groups are really the result of participation in sports, or whether the athletes remain and persit in sports because they have inherently greater capacity to cope with stress and higher self-esteem.

\section{CONFLICTS OF INTEREST}

Tha author declare that no conflicts of interest exist.

\section{FUNDING}

None.

\section{ETHICAL APPROVAL}

Ethical aproval was received form the Ethics Committee for Sport of the Faculty of Sport, University of Ljubljana.

\section{REFERENCES}

1. Gerber M, Pühse U. Do exercise and fitness protect against stressinduced health complaints?: a review of the literature. Scand J Public Health 2009; 37: 801-19.

2. Van Der Horst K, Paw MJ, Twisk JW, Van Mechelen WA. A brief review on correlates of physical activity and sedentariness in youth. Med Sci Sport Exerc 2007; 39: 1241-50.

3. Janssen I. Physical activity guidelines for children and youth. Appl Physiol Nutr Metabol 2007; 32(Suppl 2E): S109-21.

4. Eime RM, Young JA, Harvey JT, Charity MJ, Payne WR. A systematic review of the psychological and social benefits of participation in sport for adults: informing development of a conceptual model of health through sport. Int J Behav Nutr Phys Act 2013; 10: 135.

5. De Martelaer K, Theeboom M. Handbook of physical education. Thousand Oaks, London: SAGE Publications, 2006.

6. Telama R, Yang X, Hirvensalo $M$, Raitakari O. Participation in organized youth sport as a predictor of adult physical activity: a 21-year longitudinal study. Pediatr Exerc Sci 2006; 18: 76-88.

7. Bobbio A. Relation of physical activity and self-esteem. Percept Mot Skills 2009; 108: 549-57.

8. Moreno JA, Cervelló E, Moreno R. The importance of physical-sport practice and gender in physical self-concept from 9 up to 23 years. Int J Clin Health Psychol 2008; 8: 171-83.

9. Schneider M, Dunton GF, Cooper DM. Physical activity and physical self-concept among sedentary adolescent females: an intervention study. Psychol Sport Exerc 2008; 9: 1-14.

10. Donaldson SJ, Ronan KR. The effects of sports participation on young adolescents' emotional well-being. Adolesc 2006; 41: 36989.

11. Michaud P, Jeannin A, Suris J. Correlates of extracurricular sport participation among Swiss adolescents. Eur J Pediatr 2006; 165 : 546-55.

12. Brettschneider WD. Effects of sport club activities on adolescent development in Germany. Eur J Sport Sci 2001; 1: 1-11.

13. Snyder AR, Martinez JC, Bay RC, Parsons JT, Sauers EL, McLeod TC. Health-related quality of life differs between adolescent athletes and adolescent nonathletes. J Sport Rehab 2010; 19: 237-48.

14. Hansen DM, Larson RW, Dworkin JB. What adolescents learn in organized youth activities: a survey of self-reported developmental experiences. J Res Adolesc 2003, 13: 25-55.

15. Bailey R, Armour K, Kirk D. The educational benefits claimed for physical education and school sport: an academic review. Res Paper Educ 2009; 24: 1-27.

16. Mahoney JL, Stattin H. Leisure time activities and adolescent antisocial behavior: The role of structure and social context. J Adolesc 2000; 23: 112-27.

17. Emery CA, Hagel B, Morrongiello B. Injury prevention in child and adolescent sport: whose responsibility is it? Clin J Sport Med 2006; 16: $514-21$.

18. Fraser-Thomas J, Côte J. Youth sports: implementing findings and forward with research. Athletic Insight 2006; 8: 12-27.

19. Geidine S, Quennerstedt M, Eriksson C. The youth sports club as a healt-promoting setting: an integrative review of research. Scand J Public Health 2013; 41: 269-83.

20. Williams PG, Holmbeck GN, Greenley RN. Adolescent health psychology. J Consult Clin Psychol 2002; 70: 828-42.

21. Seiffge-Krenke I, Aunola K, Nurmi JE. Changes in stress perception and coping during adolescence: the role of situational and personal factors. Child Dev 2009; 80: 259-79.

22. Lazarus RS, Folkman S. Stress, appraisal, and coping. New York: Springer, 1984.

23. Folkman S, Moskowitz JT. Coping: pitfalls and promise. Annu Rev Psychol 2004; 55: 745-74.

24. Hampel P, Petermann F. Perceived stress, coping, and adjustment in adolescents. J Adolesc Health 2006; 38: 409-15. 
25. Guszkowska M. Physical fitness as a resource in coping with stress among high school students. J Sport Med Phys Fit 2005; 45: 105-11.

26. Kamtsios $S$, Filaktakidou $A$. The relation between coping strategies, self-efficiency and physical activity participation as revealed through a study held among loannina University students. Inquir Sport Phys Educ 2008; 6: 303-10.

27. Phye GD, Robinson DH, Levin JR. Empirical methods for evaluating educational interventions. San Diego: Elsevier Academic Press, 2005.

28. Frydenberg E, Lewis R, Koštal R, Boben D. Adolescent coping scale - ACS: manual. Ljubljana: Center for Psychodiagnostic Instruments, 2001.

29. Frydenberg E, Lewis R. Adolescent coping scale: manual. Melbourne: Australian Council for Educational Research, 1993.

30. Lamovec T. Manual for psychology of motivation and emotions. Ljubljana: Faculty of Arts, 1988.

31. Marsh HW, Richards G, Johnson S, Roche L, Tremayne P. Physical selfdescription questionnaire: psychometric properties and a multitraitmultimethod analysis of relations to existing instruments. J Sport Exerc Psychol 1994; 16: 270-305.

32. Skinner EA, Zimmer-Gembeck MJ. The development of coping. Annu Rev Psychol 2007; 58: 119-44.

33. Frydenberg E. Adolescent coping: advances in theory, research and practice. London: Routledge, 2008.

34. Venne SA, Laguna P, Walk S, Ravizza K. Optimism levels among collegiate athletes and non-athletes. Int J Sport Exerc Psychol 2006; 4: $182-95$.

35. Smojver-Ažić S, Anđelić-Breš S, Đonlić V. Personality traits and and coping with stress among adolescent athletes and nonathletes. In: Kinesiology new perspectives: proceedings book. Zagreb: University of Zagreb, Faculty of Kinesiology, 2002: 781-4.

36. Crews DJ, Lochbaum MR, Landers DM. Aerobic physical activity effects on psychological well-being in low-income Hispanic children. Percept Mot Skills 2004; 1: 319-24.
37. Wipfli BM, Rethorst CD, Landers DM. The anxiolytic effects of exercise: a meta-analysis of randomized trials and doseeresponse analysis. J Sport Exerc Psychol 2008; 30: 392-410.

38. Dolenc P. Physical self-perceptions of elementary school students: differences by gender and sports participation. In: Kinesiology - the path of health: proceedings book. Koper: University of Primorska, Science and Research Centre, Annales University Press, 2014: 80-9.

39. Kajtna $T$, Tušak $M$, Kugovnik $O$. Personality and motivation in male and female athletes. Psihol Obz 2003; 12: 67-84.

40. Cruz JF, Dias C, Fonseca AM. Coping strategies, multidimensional competitive anxiety and cognitive threat appraisal: differences across sex, age and type of sport. Serb J Sport Sci 2010; 4: 23-31.

41. Moksnes UK, Moljord IEO, Espnes GA, Byrne DG.The association between stress and emotional states in adolescents: the role of gender and self-esteem. Person Individ Diff 2010; 49: 430-5.

42. Krapić N, Kardum I. Coping with stress in adolescents: construction and validation of coping inventory. Drus Istraz 2003; 67: 825-46.

43. Dolenc, P. Coping with school-related stress among secondary school students. In: Education for the 21st century - creativity in education: proceedings book. Koper: University of Primorska, Science and Research Centre, Annales University Press, 2014: 61-73.

44. Matud M. Gender differences in stress and coping styles. Person Individ Diff 2004; 37: 1401-15.

45. Boden JM, Fergusson DM, Horwood LJ. Does adolescent self-esteem predict later life outcomes?: a test of the causal role of self-esteem. Dev Psychopathol 2008; 20: 319-39.

46. Kalebić Maglica B. The relationship between Eysenck personality traits, cognitive appraisals and coping strategies with adolescents mood. Drus Istraz 2006; 16: 917-41.

47. Taylor SE, Stanton AL. Coping resources, coping processes, and mental health. Annu Rev Clin Psychol 2007; 3: 377-401. 